\title{
Editorial
}

Clinical Care/Education

Diabetes Metab J 2018;42:26-27

https://doi.org/10.4093/dmj.2018.42.1.26

pISSN 2233-6079 • eISSN 2233-6087

DIABET\&S \& METABOLISM JOURNAL

\section{Self-Monitoring of Blood Glucose in Patients with Insulin-Treated Type 2 Diabetes Mellitus}

\author{
Kyung-Soo Kim \\ Department of Internal Medicine, CHA Bundang Medical Center, CHA University, Seongnam, Korea
}

Knowing the blood glucose level is very important to achieve optimal glucose control in patients with diabetes [1]. To do this, blood glucose level or glycosylated hemoglobin (HbAlc) can be checked in hospitals, by self-monitoring of blood glucose (SMBG), or using devices for glucose monitoring system at home. However, it is difficult to manage blood glucose level as it constantly changes and thus varies from the result from hospitals. In addition, continuous glucose monitoring system or flash glucose monitoring system is very effective and comfortable to patients with diabetes, but its use is not easy due to the high cost and low accessibility [2]. SMBG is an easy and convenient method for glucose monitoring in patients with diabetes [3]. Several studies have demonstrated a strong correlation between SMBG and glycemic control in patients with both type 1 diabetes mellitus and type 2 diabetes mellitus (T2DM) [4-7].

Although it is already well-known that SMBG is important for improving glucose control, it is infrequently used by patients with diabetes due to pain and inconvenience. Besides these factors, its economic aspect is also a major issue that is often neglected. In Korea, a nationwide reimbursement program for SMBG for insulin-treated T2DM patients was introduced in November 2015 [8]. The supplies were expanded to include blood glucose test strips, lancets, insulin syringes, and pen needles. This policy is expected to relieve economic burden and improve glycemic control in the beneficiaries.

Song et al. [8] investigated whether this new reimbursement program for SMBG has improved the glycemic control in pa- tients with insulin-treated T2DM. Compared to baseline (HbAlc, $8.5 \% \pm 1.3 \%)$, significantly decreased HbAlc $(8.2 \% \pm$ $1.2 \%$ ) was observed at the end of follow-up (median, 6.1 months). Baseline HbAlc and fasting serum glucose levels showed moderate-to-strong inverse correlations with changes in HbA1c $(r=-0.694, P<0.001 ; r=-0.349, P<0.001$, respectively). These results are in agreement with previous studies [4,5]. Interestingly, T2DM patients supported by the Medical Aid Program were about 2.5-fold more likely to show an improvement in $\mathrm{HbA1}$ c levels compared to patients with Medical Insurance (odds ratio, 2.459; 95\% confidence interval, 1.138 to 5.314; $P=0.022$ ). Considering that the Medical Aid Program is provided for low-income individuals as a part of social welfare programs, we could assume that economic burden is one of the major hurdles for SMBG.

Because they did not analyze the actual frequency of SMBG before and after the reimbursement, the authors could not confirm that reimbursement for SMBG increased the frequency of use. Furthermore, in future studies, long-term benefits should be assessed since this study analyzed glucose level for only 6 months after the initiation of reimbursement for SMBG. However, this study provides evidence that policies for diabetes could effectively improve glycemic control in patients with diabetes. Improving glycemic control in patients with diabetes is very important to the nation because it not only helps patients but also helps to lower healthcare costs related to diabetes.

Until now, there have been debates regarding whether SMBG
Corresponding author: Kyung-Soo Kim (iD https://orcid.org/0000-0002-7738-2284 Department of Internal Medicine, CHA Bundang Medical Center, CHA University, 59 Yatap-ro, Bundang-gu, Seongnam 13496, Korea

E-mail: kks982@hanmail.net
This is an Open Access article distributed under the terms of the Creative Commons Attribution Non-Commercial License (http://creativecommons.org/licenses/by-nc/4.0/) which permits unrestricted non-commercial use, distribution, and reproduction in any medium, provided the original work is properly cited. 
is beneficial for patients with non-insulin-treated T2DM [912]. Several studies have shown that if SMBG is properly implemented, it could improve $\mathrm{HbAlc}$ in patients with non-insulin-treated T2DM [13-15]. Because proper education and economic support is important for patients with diabetes to regularly perform SMBG, reimbursement program for SMBG will also help patients with non-insulin-treated T2DM in Korea. I will look forward to expanding this reimbursement program to all patients with diabetes.

\section{CONFLICTS OF INTEREST}

No potential conflict of interest relevant to this article was reported.

\section{REFERENCES}

1. Goldstein DE, Little RR, Lorenz RA, Malone JI, Nathan DM, Peterson CM; American Diabetes Association. Tests of glycemia in diabetes. Diabetes Care 2004;27 Suppl 1:S91-3.

2. Petrie JR, Peters AL, Bergenstal RM, Holl RW, Fleming GA, Heinemann L. Improving the clinical value and utility of CGM systems: issues and recommendations: a joint statement of the European Association for the Study of Diabetes and the American Diabetes Association Diabetes Technology Working Group. Diabetes Care 2017;40:1614-21.

3. American Diabetes Association. 6. Glycemic targets: standards of medical care in diabetes-2018. Diabetes Care 2018;41(Suppl 1):S55-64.

4. Allemann S, Houriet C, Diem P, Stettler C. Self-monitoring of blood glucose in non-insulin treated patients with type 2 diabetes: a systematic review and meta-analysis. Curr Med Res Opin 2009;25:2903-13.

5. Polonsky WH, Fisher L, Schikman CH, Hinnen DA, Parkin CG, Jelsovsky Z, Petersen B, Schweitzer M, Wagner RS. Structured self-monitoring of blood glucose significantly reduces A1C levels in poorly controlled, noninsulin-treated type 2 diabetes: results from the Structured Testing Program study. Diabetes Care 2011;34:262-7.

6. Ziegler R, Heidtmann B, Hilgard D, Hofer S, Rosenbauer J, Holl R; DPV-Wiss-Initiative. Frequency of SMBG correlates with HbAlc and acute complications in children and adolescents with type 1 diabetes. Pediatr Diabetes 2011;12:11-7.

7. Diabetes Control and Complications Trial Research Group, Nathan DM, Genuth S, Lachin J, Cleary P, Crofford O, Davis
M, Rand L, Siebert C. The effect of intensive treatment of diabetes on the development and progression of long-term complications in insulin-dependent diabetes mellitus. N Engl J Med 1993;329:977-86.

8. Song YS, Koo BK, Kim SW, Yi KH, Shin K, Moon MK. Improvement of glycosylated hemoglobin in patients with type 2 diabetes mellitus under insulin treatment by reimbursement for self-monitoring of blood glucose. Diabetes Metab J 2018; 42:28-42.

9. Young LA, Buse JB, Weaver MA, Vu MB, Mitchell CM, Blakeney T, Grimm K, Rees J, Niblock F, Donahue KE; Monitor Trial Group. Glucose self-monitoring in non-insulin-treated patients with type 2 diabetes in primary care settings: a randomized trial. JAMA Intern Med 2017;177:920-9.

10. Farmer AJ, Perera R, Ward A, Heneghan C, Oke J, Barnett AH, Davidson MB, Guerci B, Coates V, Schwedes U, O'Malley S. Meta-analysis of individual patient data in randomised trials of self monitoring of blood glucose in people with non-insulin treated type 2 diabetes. BMJ 2012;344:e486.

11. Clar C, Barnard K, Cummins E, Royle P, Waugh N; Aberdeen Health Technology Assessment Group. Self-monitoring of blood glucose in type 2 diabetes: systematic review. Health Technol Assess 2010;14:1-140.

12. Poolsup N, Suksomboon N, Rattanasookchit S. Meta-analysis of the benefits of self-monitoring of blood glucose on glycemic control in type 2 diabetes patients: an update. Diabetes Technol Ther 2009;11:775-84.

13. Barnett AH, Krentz AJ, Strojek K, Sieradzki J, Azizi F, Embong M, Imamoglu S, Perusicova J, Uliciansky V, Winkler G. The efficacy of self-monitoring of blood glucose in the management of patients with type 2 diabetes treated with a gliclazide modified release-based regimen. A multicentre, randomized, parallel-group, 6-month evaluation (DINAMIC 1 study). Diabetes Obes Metab 2008;10:1239-47.

14. Guerci B, Drouin P, Grange V, Bougneres P, Fontaine P, Kerlan V, Passa P, Thivolet Ch, Vialettes B, Charbonnel B; ASIA Group. Self-monitoring of blood glucose significantly improves metabolic control in patients with type 2 diabetes mellitus: the Auto-Surveillance Intervention Active (ASIA) study. Diabetes Metab 2003;29:587-94.

15. Schwedes U, Siebolds M, Mertes G; SMBG Study Group. Mealrelated structured self-monitoring of blood glucose: effect on diabetes control in non-insulin-treated type 2 diabetic patients. Diabetes Care 2002;25:1928-32. 